\title{
Reframing the colonial in postcolonial Lisbon
}

\author{
Placemaking and the aestheticization of \\ interculturality'
}

\section{Paulo Peixoto and Claudino Ferreira}

Cultural events are an increasingly important component of placemaking logistics and policies of aestheticization of interculturality. Festivals - a form of public celebration and a unique and ritualized moment in local life - are, in particular, an opportunity for the development of multifaceted approaches to the planning, design, and management of public spaces, offering the possibility of manipulating urban identities. This chapter examines the context of the Todos festival, aiming to reveal how the event reframes Portuguese colonial history and memory in postcolonial Lisbon through the aestheticization and intensification of interculturality. The formal participation of the local governing body (Lisbon City Council) in this cultural event makes the festival a significant dimension of the logistics of production and aestheticization of interculturality in the city of Lisbon. We argue that, both from an organizational perspective and from the viewpoint of cultural users, festivals, and Todos in particular, are a specific form of instrumentalizing culture and massifying cultural practices. In doing so, they produce and reproduce ideologies of consensus and a rhetoric of the conviviality of the differences, whose intention is to aesthetically reframe the 'contact areas' where different groups meet and struggle with each other. The rhetoric of conviviality is embodied in ways of organizing, promoting, and living the festival by emphasizing and radicalizing differences and diversity. Conviviality is thus mediated by institutional actors favouring the emergence of a festive space and a socially shared discourse that promote urban modes of togetherness.

The prominence that culture has assumed in contemporary urban intervention processes allows us to highlight two important dimensions of this chapter: the discursive and aestheticized construction of interculturality and the role of heritage as a mediator between tensions and differences that are found in culture. Placemaking, as a strategy for managing public spaces through culture, heritage, and community participation, acts both as a rhetorical mechanism and a planning tool for the production of interculturality. As highlighted by Marisa de Brito and Greg Richards, 'Increasingly [as events reinforce their attractiveness as a planning tool], public administrations seek to co-ordinate the events in their jurisdiction to create synergies between events and to maximise the benefits generated' (de 
Brito and Richards 2017, 2). The creation of the Todos festival in 2009, with the active participation of the Lisbon City Council, is part of the assumed effort to combine cultural programming, urban regeneration, and social inclusion.

In this scope, we scrutinize Todos (an event that celebrates interculturality) as a key initiative that promotes an 'ethics of tolerance' and an 'ethics of the encounter' (Edmonds 2011; Oliveira 2015) and participates in the production of new urbanscapes. We also identify heritage allegories that strategically use local multiethnicity to reconstruct urban public space and make it attractive to tourists, to gentrifiers, and for the purposes of urban leisure market. Todos-Walk of Cultures, which takes place annually in September bringing together a diverse set of activities, is part of a larger placemaking plan that seeks to affirm Lisbon as a multicultural, multiethnic, and multireligious city.

As instruments of culturalization of urban planning, the festival's initiatives occur both in spaces where the presence of minorities is felt in Lisbon's daily life and in symbolic places related to the colonial past. Giving visibility to minorities, their ways of life, their cultural and gastronomic habits, and debating racism, inclusion and difference have proven omnipresent dimensions of the past twelve festivals. Highlighting the role of events in the transition from a place-branding strategy to a placemaking strategy (Richards 2017), Todos is also a tourism event that aims to consolidate an urban marketing strategy promoted by a city that wants to be sold as a multicultural product. ${ }^{2}$ Several organizations, such as Lisbon Walker, organize tours around Todos themes; as an itinerant festival, Todos changes venues every three years. The tours tend to focus on places connected to the history of slavery, including Largo de São Domingos, Poço dos Negros, and Madragoa, seeking to show how 'the massive trade of African slaves became an essential component of the triangular commerce in the Atlantic Ocean and marked the darkest page in the History of the Discoveries' (Lisbon Walker 2020).

\section{Cultural events and placemaking}

Todos is a clear example of a placemaking approach to cultural events. The city's administration (the City Council's body responsible for cultural action) and a private non-profit association of independent cultural producers (the Academia de Produtores Culturais) partner with each other to organize the festival.

The festival's director and the main person responsible for its cultural concept and programme, Miguel Abreu, is a well-known representative of Lisbon's independent arts scene, as a theatre actor and director as well as the founder and current director of one of the first independent agencies of cultural production founded in Portugal (Cassefaz, founded in 1987). His agency is also involved in organizing the Todos festival.

The festival's concept and cultural programme is, therefore, in large part the product of the dynamics of Lisbon's cultural scene at the beginning of 
the twenty-first century and in particular of the performative arts scene. Miguel Abreu and the Cassefaz agency use the Todos festival to make an assertive and innovative statement on the performative arts scene. It is a statement directed to the artistic scene, but also to the city as a territory and a social and political community. The idea that the word Todos tried to summarize - an inclusive festival, aimed at promoting the encounter and dialogue between all sorts of people and cultures, on the one side, and an event capable of fuelling the city's territories with lively and lived cultures, on the other-was, since its initiation in 2008, both an artistic statement and a political one, taking a position on the role of culture and the arts in city planning, city life, and city image. The festival's concept and programme assume therefore the active role of culture, and cultural agents, as protagonists of the production of an urban territory and community driven by a participatory, inclusive and intercultural set of ideals and imageries.

These inclusive and participatory ideals, which mixed artistic dialogue between diverse languages and forms of cultural expression with a political conception of the city as a place of intercultural understanding and democratic coexistence, met the expectations of the political power and the local administration for the development of the city. For local authorities, the Todos festival was assumed to be part of a strategy to use culture-and culture diversity in particular - as a privileged platform to face some of the major issues the city faced in its development prospects: the integration of immigrants and ethnic minorities; the economic and social revitalization of old and traditional neighbourhoods of the city centre; the development of an ethnic market and an image of culture diversity and dynamics, as a strategy to attract tourists and middle- and upper-class consumers; the promotion of an image of a cosmopolitan and creative city as part of the economic and symbolic positioning of Lisbon in intercity competition (see Costa et al. 2017). At the inauguration of the third festival in 2011, the Mayor of Lisbon, today the Prime Minister of Portugal, António Costa, formalized Lisbon's accession to the European network of intercultural cities. ${ }^{3}$ On that same occasion, he announced the move of his office to the area (Mouraria) where the festival was being held in order to highlight the benefits of combining cultural activities with urban regeneration and requalification projects (see Oliveira and Padilla 2012).

Todos represents urban intervention where the cultural agenda of a part of the local arts community and the political agenda of local authorities converge. Consuming and assuming this convergence, the festival adopts clearly the purposes of a placemaking approach.

As declared in the official discourse of the festival, Todos focuses on 'the development of the entire community that gives meaning to the project' (Academia de Produtores Culturais 2020a). Although it is not clear what the 'entire community' means exactly, the expression emphasizes the idea of a wide and non-exclusive participation, suggesting a basis for the encounter and exchange between local residents and workers, natives, immigrants, 
tourists, artists, and consumers. The festival takes on the mission 'to make Lisbon a city where cultures intersect and help each other. Where contemporary arts help to remove barriers related to differences in ages, opinions, visions, helping to promote dialogue and respect between all' (Academia de Produtores Culturais 2020a). The motto of the 2020 festival (Todos 2020|Passengers of the World) exemplifies the close relationship between the festival's mission and the rationality of placemaking. Stating that 'the festival ... promotes and celebrates interculturality in the city of Lisbon' and it intends to 'develop the interaction between Passengers of the World, living and working in the Portuguese capital' (Academia de Produtores Culturais 2020b), the initiative seeks to bring about collaborative ways that can contribute, through culture, to improve neighbourhoods and to inspire people to collectively appropriate, reimagine, and recreate public spaces (see Zitcer 2020). Aiming to strengthen the ties between people and the places they share, in the view of its promoters, Todos is an 'opportunity ... to get to know better the places of [the] territory and what is not usually visible to our daily gaze, from the corners to reveal the stories and the community that lives in it' (Academia de Produtores Culturais 2020b).

As an event that is repeated in time and space, Todos-assuming that the community input is essential to the placemaking process - promotes the development of what Andrew Zitcer (2020) calls creative placemaking: a context in which artists, arts organizations, and community development practitioners deliberately seek to integrate, beyond the time and spaces of the festival, arts, and culture into community daily life activities.

To this extent, cultural events are an increasingly important component of placemaking logistics. Festivals in particular are an opportunity for the development of multifaceted approaches to the planning, design, and management of public spaces offering the possibility of manipulating urban identities (Jamieson 2004), insofar as the effects of the festival persist beyond the event itself.

As Kirstie Jamieson notes, in describing and analysing the Edinburgh case, although festival

spaces appear as though spontaneously formed by the company of strangers and the collective experience of performances, the city en fête is also the result of painstaking planning by a city administration that seeks to control the ways in which public spaces change.

$(2004,65)$

This institutional and planned intervention means that cities are not just stages for events, but above all, places produced through events (Richards 2017). Like the Edinburgh festival, Todos takes place as a 'framed spontaneous play which contrasts routine everyday life' of minorities (Jamieson 2004, 65). 'The bounded appeal of live performance, outdoor reveling, and alternative ways of using the city during festival time reveal how the festival gaze 
manipulates urban identity' (Jamieson 2004, 64). The carnival atmosphere surrounding the festival also means that in such events the totally unforeseen could happen.

Borrowing from Michel Foucault the concept of eventalization, one can say that festivals offer both the opportunity 'to make visible a singularity at places' and rediscover 'the connections, encounters, supports, blockages, plays of forces, strategies ... which at a given moment establish what subsequently counts as being self-evident, universal and necessary' (Foucault in Burchell et al. 1991, 76). Adopting the festival format, the event enhances the conversion of multicultural and cross-cultural logics into intercultural dynamics. In other words, the cultural and ethnic diversity of Mouraria (multiculturality) - although it may not promote engaging interactions every day - is mobilized by an event to allow the confrontation of different cultures. This confrontation is based on a cross-cultural communication, which allows differences to be perceived, opening the way to individual change. Eventalization emerges as an opportunity, based on multicultural and crosscultural dynamics, to promote collective transformation; to question the dominant culture; to force the mutual exchange of ideas; to increase deep relationships; and, by consuming interculturality, to realize an ecology of knowledge (Santos and Meneses 2010) in which everyone learns from one another and grows together.

The eventalization of urban space (Pløger 2010) requires that the relationship between events and places be made from a transversal and integrated approach (Richards 2017), so we can identify and analyse the function and importance of events in the dynamics of construction and transformation of territories.

From this perspective, approaching cultural events and their inscription in the urban fabric also implies considering the diverse forces, interests, and logics that converge, or diverge, around their staging in urban public settings and their connections to local social, cultural, and economic dynamics. As Paulo Cezar Nunes Junior (2019) demonstrated in a recent study on urban festivals in Portugal and Brazil, mass cultural events are hyperbolized examples of the growing pervasiveness of a modulatory mode of power (Deleuze 1992) that regulates and shapes social and cultural life in the commodified and culturalized city by means of decentralized, invisible, and continuously transforming technologies and devices of social control (Hui 2015).

Urban festivals are contexts of practice and experience where actions and individuated participants are modulated by the powers that frame the event's regimes of making things happen and conveying meaning. Depending on the nature of the festival, major forces framing the event's way of organizing and giving sense to practices and places can be urban policies and planning paradigms; the economic and symbolic logics of cultural, entertainment, tourism, and media industry; the symbolic economy of recognition and legitimacy that organizes competition and dispute within the arts field; or the politics of identity articulated by cultural, social, or political movements. 
Thinkers like Jonathan Beller (2006) or Michael Hardt and Antonio Negri (2001), among others, highlight the efforts to escape the cognitive and emotional chain that appears to be totalitarian and colonizes the body and the intellect and infects culture at all levels. These efforts require locating, analysing, and (re)conceptualizing resistance strategies. In this context, it is essential to highlight the minority perspectives and modes of resistance that affirm themselves in the form of corporate tactics. The positive aspect of belonging emphasized by Hardt and Negri (2001) can be found in the cultural manifestations of the festival. The sense of a mutual recognition is the basic ingredient for the multitude to react with a desire to create community.

At the same time, as eventalization becomes a growing trend in urban planning policies and strategies, festivals also become powerful devices of modulation of urban life and urban space in general, framing the urban experience in accordance to the logics of those same forces and regimes of control. The spectacularized, culturalized, commodified, and cinematic city (Boyer 1996; Reckwitz 2017) or the plastic and flexible ever-changing city is a social and cultural territory largely shaped by the same principles that frame mass events' regimes of action and sense making: a dynamic succession and accumulation of interchangeable ephemerous happenings, experiences, and sensations, organized by regimes and technologies of information that articulate the continuous resignification of places, people, memories, heritages, and practices as a cosmopolitan, individualized, subjective, and performative way of living the city.

Todos main concept Walk of Cultures illustrates the staging of events to ease people into the experience of the city of Lisbon through the mediation of cultural participation within the framework of the eventful, cosmopolitan, intercultural, and ever-changing city. This framing derives from the politics of eventalization where local authorities and urban planners, the cultural and creative sector and the arts community converge. By the mediation of Todos, together with a series of other events that shape the cultural landscape of the city, the politics of eventalization and culturalization are in the fullest sense modes of placemaking that present contemporary Lisbon as a place for both living and experiencing floating between cultures that are paradoxically exhibited to be fugaciously appropriated as daily expressions of identity.

\section{Festivals: instrumentalization of culture and massification of cultural practices}

The analysis of the impact of festivals on the organization of urban space and the emergence of new territories has become one of the most intriguing fields of research in interdisciplinary cultural studies (Brennetot 2004) in particular because they hold a potential for collective transformation. Arnaud Brennetot argues that festivals represent a new form of cultural event that became popular in the second half of the twentieth century. The author highlights that festivals are a form of reminiscence of celebrations and 
collective living that has become particularly appreciated in contemporary urban contexts (Brennetot 2004, 30).

The expansion of culture and arts festivals after the Second World War mixed the reinvention of the nineteenth century celebrations of national and local identities with the prominent role that festivals gradually assumed as tools for the international distribution, diffusion, and consecration of cultural and artistic oeuvres and practitioners. The development of cultural policies in Europe, together with the growing investment of cultural and media industries in festivals and large events as a means to distribute mass and media culture, contributed decisively to the increasing proliferation of festivals that matched the lifestyle and consumption desires and expectations of the new highly qualified urban middle classes (Autissier 2008). At the same time, from the margins of dominant and mass culture, other festivals, as settings for the experimentation of innovative and unorthodox modes of conceiving the interaction between artists, audiences, and place and bring a new political significance to festivals, arouse a more social, participatory, and inclusive tone (Quinn 2005).

Although this growing proliferation of festivals from the 1970s on, as culture gradually entered the agenda of urban policies as a potential catalyst for economic regeneration and development, festivals were invested with a new role and performativity. They became part of processes of instrumentalization of culture by urban policies (Vivant 2007), as tools for the economic regeneration and social revitalization of cities and city quarters (Evans 2001). For urban planners, city authorities, local stakeholders, and cultural intermediaries, festivals became desirable tools for various ends: for colonizing the urban landscape with the colours, sounds, and movement of a vibrant and cosmopolitan culture; for positioning the city in the international circuits of high and mass culture events; for attracting professionals and entrepreneurs from the creative industries; and for producing and marketing internationally fashionable images of a culturally dynamic city (Ferreira 2010; Quintela and Ferreira 2018; Richards and Palmer 2010). Elaborating on festivals entering the agenda of culture-led urban policies, Bernadette Quinn (2005) synthesizes three major functions that festivals take on nowadays: the festival as image maker, as tourist attraction, and as community. A fourth function should be added: the festival as arts and culture activator and mediator.

Under these conditions, festivals further proliferated and fuelled a field of increasingly diversified mainly urban intervention, as they are conceived, organized, and put into action connecting both with the arts and culture arena and the field of territorial policy and planning and increasingly with the media industry and their new digital realm.

This diversification is in line with a process of modelling, which creates festival formats and more or less formalized modes of operating culturally, economically, socially, and symbolically through festivals. The global circulation of ideas and experiences among experts and professionals of 
cultural intermediation and the development of an international professionalized market and production of events play an important role in this modelling process, one that further inflates the performativity of festivals as devices of control and regulation in the city of subjective individuals, as argued above.

Approached from this point of view, the Todos festival is a manifestation of an urban festival model that in recent decades has proliferated a little throughout the world: the 'intercultural festival' or 'multicultural festival'. Although Todos is organized according to a set of programmatic goals that are inseparable from its insertion in the city of Lisbon, it aligns with a more general trend, particularly striking in the cities of the global capitalist North. This trend reflects a meeting point between the use of cultural festivals as tools for urban regenerating and city marketing policies and as instruments of cultural and artistic intervention of a cosmopolitan, integrative, and communitarian tone - the point at which the rhetoric of the horizontal encounter and dialogue between artists and the community meets the rhetoric of the intercultural, cosmopolitan, and postcolonial city (Fincher et al. 2014).

When, in 2009, the Lisbon City Council created GLEM - Gabinete Lisboa Encruzilhada de Mundos (Lisbon crossroads of worlds office)-the municipality assumed the importance of culture and heritage in promoting strategies for urban regeneration and for reinventing the old models that were used to promote social inclusion, especially those addressed to the most marginalized areas of the city. It was in the scope of this initiative that Todos emerged, presenting itself as a project that aimed to generate bonds of solidarity, mutual knowledge, discovery and respect in the urban fabric ( $\mathrm{F}$. Brito 2020).

Since the beginning, GLEM - the municipal body responsible for the design of Todos - has developed several initiatives aimed at one of the city's most ruined historic neighbourhoods: Mouraria. ${ }^{4}$ As Marluci Menezes points out, Mouraria is a neighbourhood that represents the popular, heritage, and multicultural character of Lisbon. A place that faces a dual urban condition, crossed by countless setbacks and heterogeneities: on the one hand, the ageing of the population, the degradation and precariousness of living conditions, drug trafficking and consumption, prostitution; on the other hand, it is a dynamic neighbourhood due to the renovation brought about, in the last decades of the twentieth century, by immigrant settlement. And it is also an expressive place of culture and diversity (Menezes 2011).

Created in a context in which festivals assume themselves to be a new solution for the massification of culture, Todos becomes an instrument for building a territory for interculturality. The logic of itinerancy in the spaces of the 'Lisbon of the Other' (Martim Moniz, Mouraria, Anjos, São Vicente, etc. - neighbourhoods inhabited by citizens of foreign origin, mainly people from countries that have a historical relationship with Portugal: Brazilians, Cape Verdeans, Mozambicans, and citizens from the former Portuguese colonies in India), throughout 12 festivals, to foster, through the performing 
arts, an aesthetic of the encounter and conviviality in which the territory becomes the hero of a collective show (see Brennetot 2004, 30).

Analysing 'the city of festivals', Émilie Simard asks why festivals are so often related to the challenges associated with cultural tourism? Emphasizing that the roots of new urban economies, in post-industrial contexts, make festivals appear in a framework of ambiguity between the sphere of culture and the sphere of tourism (Simard 2010). Underlining these two dimensions and highlighting some other aspects, Elsa Vivant concludes that culture is increasingly instrumentalized for the benefit of a global urban strategy and relies on Irina van Aalst and Inez Boogaarts (Vivant 2007, 51) to conclude that, more than cultural neighbourhoods, the spaces where festivals take place, are true leisure centres where culture is just a pretext or a prefiguration of twentyfirst-century theme parks. In this perspective, the space of interculturality is a space that is aestheticized and, at the same time, essentialized. There, cities concentrate elements of attractiveness that respond more to the massification of urban tourism than to a cultural offer aimed at local inhabitants. In this circumscribed space, visitors find the necessary amenities to appropriate the space as a leisure centre. The belief in the magical role of culture as a lever in urban regeneration operations leads to the symbolic valorization of degraded neighbourhoods and an innovative cultural strategy seems necessary for the development of a city and its competitive positioning (Vivant 2007). In this context, cultural events pave the way for the radicalization of differences that, being progressively subjected to processes of escalation, is the essence of theme parks in the twenty-first century.

The celebratory interculturality that tends to characterize festivals fosters a massification of cultural practices and the massification of cultural practices reinforces the staging of celebratory interculturality. Indeed, this form of interculturality repeatedly selects the most characteristic and recognizable aspects of the otherness to show them in an exacerbated, albeit simplified and consumable, manner. The Todos initiative is not just about the days of the festival. The logistics of production and aesthetization of interculturality, which is intensely manifested in the four days of the festival, is based on the daily reconfiguration of the public space, aiming at its transformation into a hybrid space (De Molli et al. 2020; García Canclini 2013) - a space that is both a residential space of immigrant communities and a stage for the manifestation of the cultural practices of ethnic and religious minorities. As demonstrated by Marluci Menezes (2004), the neighbourhood has an intense life, where residents live with visitors, tourists, and traders. It accumulates different migratory waves (citizens of African countries who speak Portuguese, Chinese, Indians, Bangladeshis, and Pakistanis), as well as young, professional gentrifiers, who have recently settled there. The neighbourhood is now a mixture of an older population, generally associated with illegal commercial practices, and an immigrant population that gradually appropriated the public space, such as the Praça do Martim Moniz. This immigrant population is composed of Indians, Chinese, Brazilians, and Nepalis and today 
constitutes the matrix for the representation of the neighbourhood as the centre of Lisbon's interculturality.

The logic of itinerancy (one territory per triennium) allows cultural programming to develop and reveal unknown and relegated urban spaces. The regular support of cultural activities of minorities and the effort to involve them in the initiatives of the festival to give visibility to diversity are both factors that favour not only the loyalty of the public of Todos festival but also the professionalization of members of minorities in the field of gastronomy, design, performing, and visual arts, and generally in the area of culture. This logistics, reinforced over 12 festivals, makes it possible to create an 'atmosphere of enthusiasm and proliferation' (Frost 2016, 569), which ultimately characterizes the festival. As Nicola Frost stresses, 'festivalsespecially those featuring indigenous or migrant populations - have come to encapsulate, even delineate, cultural diversity as a positive social fact' (2016, 569; Florida, 2009). Cultural diversity creates an atmosphere characterized by the emergence of processes of aestheticization that result from 'being "inbetween" multiple ambiguities' (De Molli et al. 2020, 1494).

We cannot, however, fail to point out that Todos takes place in a 'contact zone' (Ifversen 2018; Pratt 1991; Santos and Meneses 2010) where different cultures meet and struggle with each other, usually in unequal conditions. A kind of an 'intercultural hybridity' (Collado 2016; García Canclini 2013) functioning as a reality capable of producing ambivalent and contradictory identities (which are at times structured in a dialogical relationship and at other times become entities that ignore or oppose each other). And also the ex libris of a 'concept city' (de Certeau 1998) of a former colonial capital that converts interculturality into performance. This unveils the 'complexity of interculturality' and brings out the risk of 'essentializing identities and of caging others in stereotypes' (Ifversen 2018). The festival tends-from an organizational perspective - to produce attractive otherness that covers up the political tensions and incommensurabilities (linguistic, religious, gastronomic, etc.) in the contact zones.

\section{Reframing the colonial in postcolonial Lisbon}

The heterogeneity and the diversity (seen as a resource of the cultural programming of Todos) result from historical processes based on social arrangements of two different major periods: one, the older, linked to the Portuguese colonial process; the other, more recent and partly related to the former, linked to the dynamics of migration and refugee flows that choose to live and work in Lisbon.

In this context, heritage is seen by the organizers of Todos as a mediator between tensions and differences found in culture. One can say that the space and time where the festival takes place correspond to the formula of the third space, in the sense given to it by Homi K. Bhabha (1994). This meta concept 
of postcolonial sociolinguistic theory of identity and community, which turns us all into hybrids, explains the transformation of individual identities from the opportunities for interaction and negotiation of meanings framed by coexistence with otherness. In this sense, the rhetoric of the festival falls within the scope of the concept of the third space. Nestór Garcia Canclini (2013) argues that heritage does not have a mere cultural dimension. More than cultural, heritage is intercultural in the sense that it embodies the opposing and confronting differences as a result of cultural hybridization. The public support given to the different communities, the aid for development of ethnic trade, the public policies for the promotion of religious tolerance, the visibility given to newcomers in official Lisbon City Hall publications, are examples of the ways public agents seek to value and use differentiated heritage to aestheticize and foster interculturality on a daily basis. The festival replicates, in a celebratory and interactive logic, the cultural sharing between heterogeneous groups. The spectacularization of difference is part of this effort to hybridize taking heritage as a major resource.

In the wake of Canclini's argument, as in many other cities marked by a long and dense colonial history whose inscriptions remain on the materiality and immateriality of several places and memories of those cities, postcolonial Lisbon of the twenty-first century is confronted with the need to keep up with the trends of recognition of the identities of minorities. However, the recognition of the heritage dimension and the cultural valorization of minorities were slow and selective. The major cultural projects of the late twentieth century, such as the world exhibition Expo 98 (Ferreira 2006), as well as the cultural projects and proposed cultural facilities of the first two decades of the twenty-first century, and the current priorities of the Lisbon tourist industry reveal weak recognition of the Afro descendant heritage and the limited access for minorities to sites and heritage resources. One could say from Lisbon what Cesar Augusto Velandia Silva and Juan José OspinaTascón conclude regarding Cartagena das Indias: 'The challenge of [Lisbon's] heritage role is to try to reverse this double image of the city and its links with its inhabitants. ${ }^{5}$ It must be reinforced by a process of education and reconquest of heritage spaces by Afro-[descendants]. This is how the interculturality of heritage acquires the capacity to balance people's hopes and needs' (Silva and Ospina-Tascón 2020).

The festival is an initiative that intends to reframe the colonial in postcolonial Lisbon. It assumes the mission of ensuring the transition from a multicultural perspective (which only recognizes the diversity that separates the communities) to an intercultural perspective (which presupposes the existence of interactions, confrontation, and exchange between different communities).

Twelve festivals have been completed, and we can conclude that the founding ideology of the festival has been incorporated by the festival-goers. The testimony of one of our interviewees ${ }^{6}$ is an example of this: 
The first thing I said to my wife is that they discover every year spaces in Lisbon that the Lisboners do not know and do not appreciate. In our daily life, we don't have access to these spaces. And they somehow managed to realize that these places exist and transform the spaces, which were formerly linked to other activities, through culture. This is what I like most about the festival. The second thing I like the most is precisely this integration of cultures. In other words, I believe that racism is born out of ignorance of the other. And getting to know the other is a way for us to realize how close we are to each other.

(David, 43)

It is also clear that placemaking dynamics have contributed, from the festival-goers' perspective, to the regeneration and de-stigmatization of neighbourhoods inhabited by minorities. Urban rehabilitation operations, policies of positive discrimination of businesses exploited by Afrodescendants and other minorities, a policy of active mobilization of cultural agents involved in the festival Todos and the creation of opportunities for these agents to become professional, as well as the development of institutional communication aimed at valuing the diversity guaranteed by minorities are factors that allow for a reframing of stereotypes, favouring a postcolonial imaginary fuelled by the aestheticization of interculturality (Figure 11.1).

The festival is an opportunity to rediscover these neighbourhoods. Mouraria has changed completely in the past ten years. They have really contributed a lot to this. I lived nearby and never passed through Mouraria; I went down Avenida Almirante Reis. Now I always pass by Rua do Bemformoso, from behind. So, for me, the festival completely changed the image of the neighbourhood. I was convinced that, there, it was just drugs and prostitution. That exists. But there are many other things. I now also go through that place.

(Ana, 51)

The analysis of the answers to two questions included in the interview script are shown in a cloud of words (Figure 11.1) that reveals the way festivalgoers incorporate the ideology of Todos. ${ }^{7}$ Interculturality (although often referred to as 'multiculturalism') is by far the most used expression to characterize the festival and the atmosphere permeating the city. This word, which has defined the ethos of the event since its premiere, is reinforced by other terms that contribute to the aesthetic dimension of interculturality. The word culture, in the contexts in which it is used in the responses of festival-goers, translates not only the importance of culture in the transformation of the place and in urban regeneration, but also, and above all, the valorization of a culture that allows the projection of diversity, inclusion, discovery of the territory, and engagement. And that, representing the spirit of postcolonial 


\section{Discovery of the territory

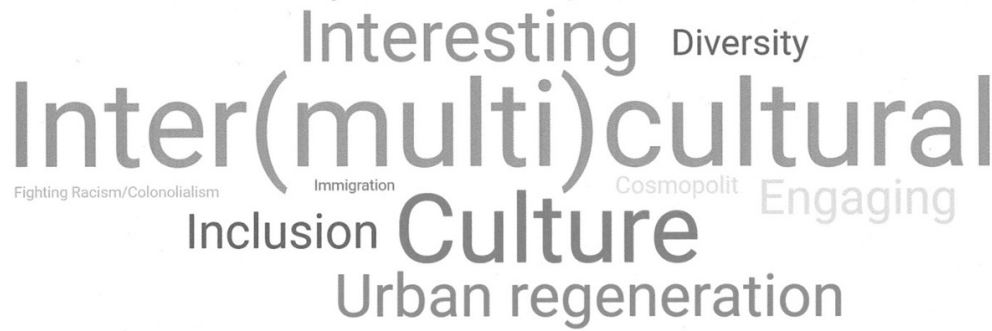

Figure II.I Cloud of words to characterize the festival or the relationship of the festival with the city.

Lisbon, makes the event and its manifestation in urban space an interesting phenomenon.

Although the specific dimension of racism and colonialism are not the most evident in the festival-goers' responses, the role of the festival in this dimension is recognized by several interviewees.

I'm not going to tell you that the festival is opening minds. It doesn't work that way. But I think it is important to know and learn from other cultures in order to understand the roles and importance of communities. As European colonisers, it is important to learn at least a little from other cultures in order to eliminate this racist structure in which we live. In this respect, the festival seems important to me. A festival of this kind forces us to confront other realities.

(Frederico, 27)

The reframing of colonial processes in postcolonial readings, such as the Todos festival intends to achieve, is all the more important as the event is assumed to be specifically aimed at the Portuguese. In a recent interview, the head of the Lisbon municipality for culture declared the ambition of the festival to contribute to the inclusion of minorities and to the fight against racism and xenophobia.

Todos has always been designed for residents. It has never been a festival for tourists or Erasmus students. In fact, it has always had the objective of looking at the diversity of the city's communities, and trying to bring them into the daily life of Lisbon, and, above all, I believe, the objective of making that diversity visible to the people of Lisbon, while creating inclusion mechanisms for all those people who are often outside the arts and culture circuits. This was the initial commitment of Todos and it is 
the commitment that remains, and the time in which we live reinforces this need, due to the emergence, throughout the world, of racist and xenophobic movements, at a time when we are witnessing a great fragmentation of the communities themselves, and therefore this objective of inclusion, of the link between the communities, of the creation of cohesive communities, in a logic of proximity, remains.

(Catarina Vaz Pinto in Adamopoulos and Reis 2020)

\section{Conclusions}

Seeking to highlight the process of producing a performed interculturality that aims to reframe the colonial and the otherness in an aesthetic dimension, we start from the concept of placemaking in order to accomplish a contemporary analysis of Lisbon's historic neighbourhoods and the challenges they face at a time of urban requalification operations, escalating tourism, and the realization of cultural events.

We specifically analysed the Todos festival, the twelfth completed in 2020, which sees itself as an event to promote interculturality, as it adopted the logics of placemaking and the narratives of post-coloniality. Initiatives such as the Todos Orchestra - which was one of the first to be consolidated and to assume a structural character, acting as the festival's brand image in the time and space that exist beyond the moment of the festival (every September)or more recent ones, such as Todos Saberes e Sabores Culturais (Todos knowledge and cultural flavours), which promotes the gastronomic heritage of minorities, as well as collective exhibitions of artists featuring sketches of foreign businesses in the streets of Lisbon focused on immigrant entrepreneurship underpin the role of heritage as a mediator between tensions and differences that are found in local culture. As if the inevitability of daily coexistence with the heritage of the others would end up provoking a flattening of the contested character of the heritage. Contributing to sustain the rhetoric that states that Lisbon is a place of intercultural dialogue, where diversity is not only tolerated, but protected and stimulated.

When we asked festival-goers to reflect on their experience, what they think of the festival, and the importance of the festival for the city, what is notable is that they do not evoke specific venues. Rather, they frequently reproduce the narratives of the ethics of the encounter and the importance of the festival to contribute to discovering the territory and the otherness. In the interviews, Todos is described as being 'interesting', 'cosmopolite', and 'engaging'.

Initiatives such as the Todos festival must, however, be placed in the context of all the cultural initiatives and projects that political actors want to implement in a city that has become a major tourist attraction on an international scale. If, on the one hand, Todos is an event that intends to promote interculturality, acting in marginalized areas of the city, on the other 
hand, in the noblest and most recognized spaces, projects are designed and approved that reproduce the domination of cultural and heritage hegemonies. But at least symbolically, by providing the conviviality of racialized working classes, immigrants, and ethnic minorities, Todos also functions as a tool for questioning the security claims and practices that stigmatize minorities and vulnerable groups.

\section{Notes}

1 This chapter is part of the project ECHOES European Colonial Heritage Modalities in Entangled Cities that has received funding from the European Union's Horizon 2020 research and innovation programme under grant agreement No. 770248.

2 The festival is promoted by the Academia de Produtores Culturais (a private agent) and the Municipality of Lisbon (a public agent responsible for the governance of the city).

3 In 2012, Lisbon took a prominent place in the creation of the Portuguese network of Intercultural Cities (RPCI), which now includes 11 municipalities from different regions of Portugal. The network is seen as a response to the diversification of Portugal's ethnic landscape from the 1990s when Portugal began to receive immigrants to work and live. In the middle of the last decade, the foreign population with legal status reached nearly 400,000 people. Brazil was the largest community, followed by Cape Verde, Ukraine, Romania, China, and Angola (see 'The Portuguese Network of Intercultural Cities', Council of Europe. Accessed 5 March 2021. https://www.coe.int/en/web/interculturalcities/ portugal).

4 Mouraria (literally, the Moorish quarter) is the place in Lisbon where the Moors, who did not leave the city with the Christian reconquest (1147), settled.

5 On one side, this double image is a city dominated by the 'traditional notion of white and Catholic elite heritage'. From other side, it is a city marked by 'a plural notion of Afro-Colombian, indigenous, peasant and pagan heritage'.

6 At the eleventh festival (2019), we carried out 45 interviews with festival-goers in the venues of Todos festival. The interviews were carried out in the vox pop modality. The interview script contained six questions. The answers were recorded and transcribed and analysed using MaxQda software. The 45 interviewees were randomly selected. 31 were Portuguese; 3 French; 2 Brazilian; 2 Italian; 2 Angolan; 1 Albanian; 1 Syrian; 1 Guinean; and 2 had dual nationality; 29 had attended previous editions of the festival and 16 were participating for the first time. Quotations from attendees were presented under pseudonyms along with their ages.

7 The two questions whose answers were retained for this analysis are: What is your opinion about Todos festival? How important is the festival for the city?

\section{References}

Academia de Produtores Culturais. 2020a. "Entre todos-Festival Todos." Todos. Accessed 5 March 2021. https://www.festivaltodos.com/entre-todos/.

Academia de Produtores Culturais. 2020b. "TODOS 2020|Passengers of the World." Todos. Accessed 5 March 2021. https://www.festivaltodos.com/en/festival/. 
Adamopoulos, Sarah, and Rosa Reis. 2020. "TODOS: A Arte de Caminhar Juntos." Todos. Accessed 5 March 2021.https://www.festivaltodos.com/en/news-todos/ todos-a-arte-de-caminhar-juntos/.

Autissier, Anne-Marie, ed. 2008. L'Europe des festivals: De Zagreb à Édimbourg, points de vue croisés. Toulouse: Saint-Denis: Attribut.

Beller, Jonathan. 2006. The Cinematic Mode of Production: Attention Economy and the Society of the Spectacle. Hanover: Dartmouth College Press.

Bhabha, Homi K. 1994. The Location of Culture. London: Routledge.

Boyer, M. Christine. 1996. The City of Collective Memory: Its Historical Imagery and Architectural Entertainments. Cambridge: The MIT Press.

Brennetot, Arnaud. 2004. "Des Festivals Pour Animer Les Territoires/When French Art Festivals Bring Life to Living Places.” Annales de Géographie 113 (635): 29-50. https://www.jstor.org/stable/23456364.

Brito, Flávia. 2020. "Passageiros pelo mundo, somos Todos." Gerador, 18 September 2020. https://gerador.eu/passageiros-pelo-mundo-somos-todos/.

Burchell, Graham, Colin Gordon, and Peter Miller, eds. 1991. The Foucault Effect: Studies in Governmentality: With Two Lectures by and an Interview with Michel Foucault. Chicago: University of Chicago Press.

Collado, Alicia. 2016. "The Return to the Homeland: Pilar's Intercultural Hybridity in Dreaming in Cuban.” Revista de Culturas y Literaturas Comparadas 6: 1-11.

Costa, Pedro, Ana Oliveira, Andreia Magalhães, Filipa Alves de Sousa, Giles Teixeira, Paula Guerra, and Tânia Moreira. 2017. Estratégias para a cultura da Cidade de Lisboa 2017. Lisbon: Câmara Municipal de Lisboa.

de Brito, Marisa, and Greg Richards. 2017. "Events and Placemaking." International Journal of Event and Festival Management 8 (January): 2-7.

de Certeau, Michel. 1998. A Invenção Do Cotidiano. Petrópolis: Vozes.

de Molli, Federica, Jeanne Mengis, and Alfons van Marrewijk. 2020. "The Aestheticization of Hybrid Space: The Atmosphere of the Locarno Film Festival." Organization Studies 41 (11): 1491-512. https://doi.org/10.1177/0170840619 867348.

Deleuze, Gilles. 1992. "Postscript on the Societies of Control." October 59: 3-7. https://www.jstor.org/stable/778828.

Edmonds, Jeff. 2011. "Toward an Ethics of the Encounter: William James's Push Beyond Tolerance." The Journal of Speculative Philosophy 25 (2): 133-47. https:// doi.org/10.5325/jspecphil.25.2.0133.

Evans, Graeme. 2001. Cultural Planning: An Urban Renaissance? London: Routledge.

Ferreira, Claudino. 2006. "A Expo'98 e os imaginários do Portugal contemporâneo: cultura, celebração e políticas de representação.” $\mathrm{PhD}$ diss., Universidade de Coimbra. https://estudogeral.sib.uc.pt/handle/10316/482.

Ferreira, Claudino. 2010. "Cultura e regeneração urbana: novas e velhas agendas da política cultural para as cidades." Tomo 16: 29-56. https://doi.org/10.21669/tomo. v0i16.518.

Fincher, Ruth, Kurt Iveson, Helga Leitner, and Valerie Preston. 2014. "Planning in the Multicultural City: Celebrating Diversity or Reinforcing Difference?" Progress in Planning 92 (August): 1-55. https://doi.org/10.1016/j.progress.2013.04.001.

Florida, Richard. 2009. Who's Your City?: How the Creative Economy Is Making Where to Live the Most Important Decision of Your Life. New York: Basic Books.

Frost, Nicola. 2016. "Anthropology and Festivals: Festival Ecologies." Ethnos 81 (4): 569-83. https://doi.org/10.1080/00141844.2014.989875. 
García Canclini, Néstor. 2013. Culturas híbridas: Estrategias para entrar y salir de la modernidad. Paidós estado y sociedad 87. Barcelona: Paidós.

Hardt, Michael, and Antonio Negri. 2001. "Adventures of the Multitude: Response of the Authors." Rethinking Marxism 13 (3-4): 236-43. https://doi.org/10.1080/ 089356901101241929.

Hui, Yuk. 2015. "Modulation after Control.” New Formations (84-85): 74-91. https:// doi.org/10.3898/NEWF:84/85.04.2015.

Ifversen, Ian. 2018. "Interculturality." In Keywords $\mid$ Echoes-Anthology Exploring the Keywords of Colonial Heritage, edited by Andersen Casper, Britta Timm Knudsen, and Christoffer Kølvraa. https://keywordsechoes.com/interculturality.

Jamieson, Kirstie. 2004. "Edinburgh: The Festival Gaze and Its Boundaries." Space and Culture 7 (1): 64-75. https://doi.org/10.1177/1206331203256853.

Junior, Paulo Cezar Nunes. 2019. "Festivais Como Moduladores Da Cidade Contemporânea Diálogos Entre São Paulo e Lisboa.” PhD diss., Universidade de Coimbra.

Menezes, Marluci. 2004. Mouraria, retalhos de um imaginário: significados urbanos de um bairro de Lisboa. Oeiras: Celta Editora.

Menezes, Marluci. 2011. "Todos na Mouraria? Diversidades, desigualdades e diferenças entre os que vêm ver o bairro, nele vivem e nele querem viver." Paper presented at XI Luso-Afro-Brazilian Congress of Social Sciences CONLABDiversities and (Dis) EqualitiesSalvador, 7-10 August 2011, Federal University of Bahia (UFBA). https://doi.org/10.13140/RG.2.1.3502.9206.

Oliveira, Nuno. 2015. "Producing Interculturality: Repertoires, Strategies and Spaces." New Diversities 17 (1): 129-43.

Oliveira, Nuno, and Beatriz Padilla. 2012. "A diversidade como elemento de desenvolvimento/atração nas políticas locais urbanas: contrastes e semelhanças nos eventos de celebração intercultural." Sociologia, Revista da Faculdade de Letras da Universidade do Porto, n. Número temático: Imigração, Diversidade e Convivência Cultural: 129-62.

Pløger, John. 2010. "Presence-Experiences-The Eventalisation of Urban Space". Environment and Planning D: Society and Space 28 (5): 848-66. https://doi. org/10.1068/d1009.

Pratt, Mary Louise. 1991. "Arts of the Contact Zone.” Modern Language Association: Profession: 33-40. https://www.jstor.org/stable/25595469?seq=1.

Quinn, Bernadette. 2005. "Arts Festivals and the City." Urban Studies 42 (5-6): 92743. https://doi.org/10.1080/00420980500107250.

Quintela, Pedro, and Claudino Ferreira. 2018. "Indústrias culturais e criativas em Portugal: um balanço crítico de uma nova 'agenda' para as políticas públicas no início deste milénio.” Todasas Artes 1 (1): 88-110. https://doi.org/10.21747/21843805/ tav1n1a6.

Reckwitz, Andreas. 2017. The Invention of Creativity: Modern Society and the Culture of the New. Malden: Polity.

Richards, Greg. 2017. "From Place Branding to Placemaking: The Role of Events." International Journal of Event and Festival Management 8 (1): 8-23. https://doi. org/10.1108/IJEFM-09-2016-0063.

Richards, Greg, and Robert Palmer. 2010. Eventful Cities: Cultural Management and Urban Revitalisation. Amsterdam: Butterworth-Heinemann.

Santos, Boaventura de Sousa, and Maria Paula Meneses. 2010. Epistemologias do Sul. Coimbra: Almedina: CES. 
Silva, Cesar Augusto Velandia, and Juan José Ospina-Tascón. 2020. "Intercultural Landscapes: Towards an Interpretation.” edA Esempi di Architettura 1 (text 5). http://www.esempidiarchitettura.it/sito/journal_pdf/PDF\%202020/5.\%20 EDA_2020_VELANDIA_OSPINA.pdf.

Simard, Émilie Julie. 2010. "'Montréal, ville de festivals' entre culture et tourisme culturel: le cas de Montréal en lumière." MA thesis, Université du Québec à Montreal.

Vivant, Elsa. 2007. "L'instrumentalisation de la culture dans les politiques urbaines: un modèle d'action transposable?" Espaces et societes 131 (4): 49-66. https://www. cairn.info/revue-espaces-et-societes-2007-4-page-49.htm.

Lisbon Walker. 2020. “African Presence.” Lisbon Walker. Accessed 5 March 2021. https://lisbonwalker.com/packages/african-presence-for-schools/.

Zitcer, Andrew. 2020. "Making Up Creative Placemaking." Journal of Planning Education and Research 40 (3): 278-88. https://doi.org/10.1177/0739456X18773424. 